DOI: https://doi.org/10.36910/6775-2524-0560-2020-41-34

УДК: 621.397 .13

Терлецький Тарас Володимирович, к.т.н., доцент, https://orcid.org/0000-0002-4114-0734

Ткачук Анатолій Анатолійович, к.т.н., ст. викладач

https://orcid.org/0000-0001-9085-7777

Кайдик Олег Леонтійович, к.т.н., доцент,

https://orcid.org/0000-0002-3620-270X

Цебрук Віталій Романович

Луцький національний технічний університет, м. Луцьк, Україна.

\title{
КРИТЕРІЇ ВИРІШЕННЯ ОПЕРАТИВНИХ ЗАДАЧ СВІТОВИХ СТАНДАРТІВ ІНФОРМАЦІЙНИХ СИСТЕМ ССТV
}

Терлецький Т.В., Ткачук А.А., Кайдик О.Л., Цебрук В.Р. Критерії вирішення оперативних задач світових стандартів інформаційних систем CCTV. Проведено аналіз критеріїв вирішення оперативних задач інформаційними телевізійними системами спеціального призначення CCTV, що регламентують відповідні стандарти різних держав. Встановлено розбіжність їх величин в стандартах i, у відповідності до теорії зміни просторової щільності пікселів та тенденцій постійного збільшення роздільної здатності матриць, висунуто припущення про граничне значення роздільної здатності відеокамер, досягнення якої обумовить подальшу доцільність використання цих критеріїв, та визначено шляхи реалізації цього завдання.

Ключові слова: критерії, оперативна задача, щільність пікселів, матриця, якість зображення, сцена, просторова роздільна здатність.

Терлецкий Т.В., Ткачук А.А., Кайдик О.Л., Цебрук В.Р. Критерии решения оперативных задач мировых стандартов информационных систем CCTV. Проведен анализ критериев решения оперативных задач информационными телевизионными системами специального назначения CCTV, которые регламентируют соответствующие стандарты разных стран. Установлено расхождение их величин в стандартах и, в соответствии с теорией изменения пространственной плотности пикселей и тенденций постоянного увеличения разрешения матриц, выдвинуто предположение о предельном значение разрешения видеокамер, достижение которой обусловит дальнейшую целесообразность использования этих критериев, и определены пути реализации этой задачи.

Ключевые слова: критерии, оперативная задача, плотность пикселей, матрица, качество изображения, сцена, пространственное разрешение.

Terletskyi T.V, Tkachuk A.A, Kaidik O.L, Cebruk V.P. Criteria for solving operational problems of world standards of CCTV information systems. The analysis of the criteria for solving operational problems by special-purpose information television systems CCTV, which regulates the relevant standards of different countries. The discrepancy between their values in the standards was established and, in accordance with the theory of changes in the spatial density of pixels and the tendencies of a constant increase in the matrix resolution, an assumption was made about the limiting value of the resolution of video cameras, the achievement of which would determine the further expediency of using these criteria, and the ways of implementing this task were determined.

Key words: criteria, operational task, pixel density, matrix, image quality, scene, spatial resolution.

Відеоспостереження відноситься до інформаційних телевізійних систем спеціального призначення, які називають замкнутим або закритим прикладним телебаченням Closed Circuit Television (CCTV) та для обмеженого числа глядачів, на відміну системам мовного телебачення. 3'явилося CCTV на початку другої половині 20 століття та являло собою аналогову систему отримання зображення, його якість не регламентувалась жодним нормативним документом.

Виробляючи рекомендації з вибору камер і обговорюючи, яка 3 них представлена на ринку краще, виробники зводили все до технічних описів та специфікацій. У результаті розробники CCTV не брали до уваги одну з ключових вимог будь-якої системи відеоспостереження - експлуатаційні вимоги, або фактичну мету відеоспостереження.

Одним 3 основних параметрів, який враховується при виборі камери відеоспостереження $\epsilon$ ступінь деталізації зображення. Залежить він від чіткості відображення об'єкта спостереження на відповідному засобі та визначається завданнями, що стоять перед системою. 3 появою терміну «оперативна задача» та ідеї «операційних стандартів», яка була сформульована у Великобританії на при кінці 80-х років минулого століття, виник один з перших світових стандартів охоронних систем BS 8418:1987. Цей стандарт, отримав неформальну назву - «Британський стандарт CCTV».

Згідно BS 8418:1987, в аналоговому відеоспостереженні вибір камери під конкретні експлуатаційні вимоги зводився до вибору потрібного об'єктиву. Більшість таких CCTV 
призначалося для стеження за поведінкою людей, тому в якості еталонного об'єкта в них використали постать людини (рис. 1).

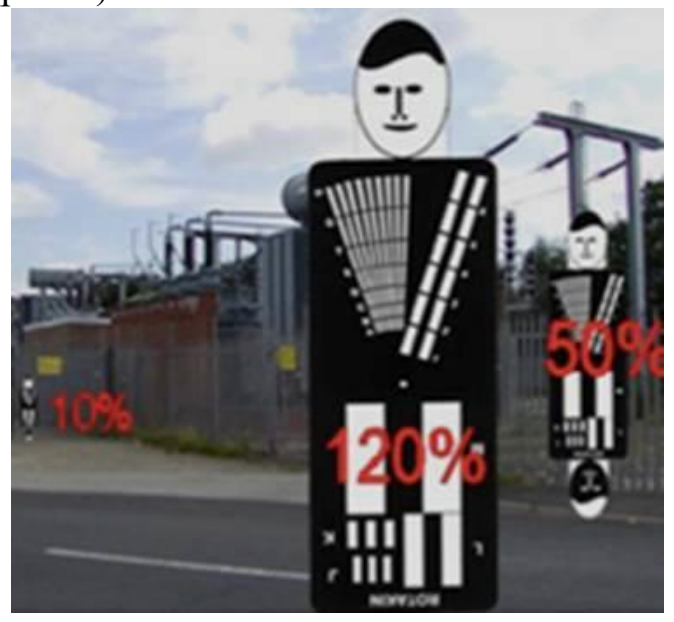

Рис. 1. Відображення тестового манекену на 10\%, 50\% і 120\% від висоти зображення

У «Британському стандарті» 1987 року було сформульовано відповідні категорії, які відрізнялися тим, яку частину кадру займає людина в повний зріст, і затверджено перші критерії, яким має відповідати система відеоспостереження для вирішення оперативних задач (табл. 1).

Таблиця 1. Критерії вирішення оперативного завдання CCTV стандарту BS 8418:1987

\begin{tabular}{|c|l|c|}
\hline $\begin{array}{c}\text { Оперативне } \\
\text { завдання }\end{array}$ & \multicolumn{1}{|c|}{ Експлуатаційні вимоги } & $\begin{array}{c}\text { Людський } \\
\text { зріст, \% }\end{array}$ \\
\hline Ідентифікація & $\begin{array}{l}\text { Деталізація повинна дозволяти ідентифікувати людину 3 } \\
\text { впевненістю, що виключає розумний сумнів }\end{array}$ & $100-150$ \\
\hline Розпізнавання & $\begin{array}{l}\text { Можливість 3 високою впевненістю визначити ідентичність людини } \\
\text { на зображенні тій, яку раніше бачили }\end{array}$ & 50 \\
\hline Виявлення & $\begin{array}{l}\text { Можливість 3 високою впевненістю визначити наявність людини в } \\
\text { кадрі }\end{array}$ & 10 \\
\hline
\end{tabular}

3 розвитком аналогового відеоспостереження і покращенням роздільної здатності зображення було переглянуто категорії оперативних задач. 3 огляду на це, стандарт BS 8418:1987 трансформували у BS 8418:2009, де виділили наступні оперативні завдання: моніторинг, детектування, огляд, розпізнання, ідентифікація та інспектування. Ці завдання різняться від попередніх. Завдання моніторингу, згідно BS 8418:2009, полягає в оцінці загальної ситуації в контрольованій зоні. Це передбачає загальний огляд та оцінку ситуації в цілому, без дрібних деталей. Наприклад, спостереження за територією, що прилягає до входу в будівлю, або за ситуацією у вестибюлі метро (виникнення скупчення людей може призвести до тисняви). Можливість оцінити деталі не тільки дрібні (номер автомашини, обличчя людини тощо), але і більші (марку автомашини, наявність предметів в руках людей) зазвичай відсутня.

Завдання детектування передбачає гарантоване виявлення суб’єктів чи об'єктів спостереження в контрольованій зоні. Спостереження полягає у визначенні грубих характерних особливостей об'єкта чи суб'єкта спостереження 3 подальшим спостереженням за їх переміщенням 3 метою виявлення несанкціонованих або потенційно небезпечних дій.

Мета завдання розпізнавання - визначення приналежності суб'єкта або об'єкта спостереження чи їх елементів до певної групи об'єктів спостереження.

Вирішення завдання ідентифікації потребує можливість розрізняти досить дрібні, характерні деталі, наприклад особи людини, що входить на об'єкт, або номерний знак автотранспорту. Таким чином, ідентифікація - це процес впізнання суб'єкта або об'єкта по властивому йому або наданим йому ідентифікаційним ознакам. Оскільки, в аналогових системах відеоспостереження роздільна здатність визначається кількістю телевізійних ліній (ТВЛ) - то і вимоги до розв'язання поставленого завдання в «Британському стандарті» 2009 і 2015 років охоронних систем [4] залишилися виходячи 3 того, яку частину кадру за вертикаллю повинен займати об’єкт спостереження (табл. 2). 
Таблиця 2. Критерії вирішення оперативних завдань CCTV стандарту BS 8418:2015

\begin{tabular}{|c|c|c|c|c|}
\hline № & Вид активності & Задачі і можливості & $\begin{array}{c}\text { Висота } \\
\text { відображення } \\
\text { в кадрі від } \\
\text { загальної } \\
\text { його висоти в } \\
\text { камерах PAL, } \\
\%\end{array}$ & $\begin{array}{c}\text { Висота } \\
\text { відображення } \\
\text { в кадрі від } \\
\text { загальної } \\
\text { його висоти в } \\
\text { камерах } \\
\text { NTSC, \% }\end{array}$ \\
\hline 1 & Моніторинг & моніторинг і контроль натовпу & 5 & 5 \\
\hline 2 & Детектування & гарантоване виявлення людини в кадрі & 10 & 10 \\
\hline 3 & Спостереження & $\begin{array}{l}\text { визначення характерних особливостей } \\
\text { людини, наприклад одягу }\end{array}$ & 25 & 30 \\
\hline 4 & Розпізнавання & розпізнавання знайомих оператору людей & 50 & 60 \\
\hline 5 & Ідентифікація & якість, достатня для ідентифікації людини & 100 & 120 \\
\hline 6 & Інспектування & $\begin{array}{l}\text { можливість } 100 \% \text { ідентифікації, яка } \\
\text { виключає сумнів }\end{array}$ & 400 & 400 \\
\hline
\end{tabular}

Ірландський I.S. 199:1987 [6], Австралійський і Новозеландський AS 4806.2-2006 [7] та інші стандарти з CCTV тих часів також використовували подібні критерії для вирішення того чи іншого оперативного завдання.

У 2013 році Європейський комітет з стандартизації в електротехніці, з метою уніфікації в проектуванні CCTV в СC і беручи до уваги дані «Британського стандарту CCTV», видав стандарт у даній сфері EN 50132-7 під назвою «Системи відеоспостереження охоронного телебачення» [8]. В європейському стандарті сформовано критерії вибору камер і об'єктивів до них, критерії для визначення кількості та розташування камер, методики оцінки сцени і освітлення, а критерії вирішення оперативного завдання CCTV відповідали «Британському стандарту» 2009 року. Характерною відмінністю європейського стандарту від BS 8418:2009 [10] була поява альтернативного параметра - «щільність пікселів» на одиницю ширини об'єкта спостереження (табл. 3), що пояснюється появою на ринку камер, які функціонували за іншим принципом ніж аналогові. Подальша доцільність використання показників даних критеріїв була обумовлена появою мегапіксельних цифрових систем CCTV і часом, протягом якого старі аналогові системи існували поруч з ними - поки останні не витіснили з ринку перших.

Таблиця 3. Критерії вирішення оперативних завдань CCTV стандарту EN 50132-7

\begin{tabular}{|c|c|l|c|c|c|}
\hline № & Вид активності & \multicolumn{1}{|c|}{ Задачі і можливості } & $\begin{array}{c}\text { Старий } \\
\text { параметр, \% } \\
\text { висоти } \\
\text { кадру }\end{array}$ & $\begin{array}{c}\text { Альтернатив } \\
\text { ний } \\
\text { параметр, } \\
\text { мм/1пкс }\end{array}$ & $\begin{array}{c}\text { Кількість } \\
\text { пікселів на } \\
\text { 1 м за } \\
\text { горизонтом }\end{array}$ \\
\hline 1 & Моніторинг & $\begin{array}{l}\text { моніторинг і контроль } \\
\text { натовпу }\end{array}$ & 5 & 80 & 12 \\
\hline 2 & Детектування & $\begin{array}{l}\text { гарантоване виявлення } \\
\text { людини в кадрі }\end{array}$ & 10 & 40 & 25 \\
\hline 4 & Спостереження & $\begin{array}{l}\text { визначення характерних } \\
\text { особливостей людини, } \\
\text { наприклад одягу }\end{array}$ & 25 & 16 & 62 \\
\hline 5 & Ідентифікація & $\begin{array}{l}\text { якість, достатня для } \\
\text { ідентифікації людини } \\
\text { оператору людей }\end{array}$ & 100 & 4 & 250 \\
\hline 6 & Інспектування & $\begin{array}{l}\text { можливість 100\% } \\
\text { ідентифікації, яка виключає } \\
\text { сумнів }\end{array}$ & 400 & 1 & 1000 \\
\hline
\end{tabular}

3 домінуванням на ринку IP та HD камер застосовують тільки новий спосіб встановлення відповідності експлуатаційним вимогам. Процентні співвідношення відійшли у минуле і стосовно

( Терлецький Т.В., Ткачук А.А., Кайдик О.Л., Цебрук В.Р. 
цифрових камер не використовують, а вимоги до роздільної здатності вказують тільки в пікселях (замість ТВЛ) - кількість пікселів зображення на 1 м на відстані спостереження за об'єктом. Таким чином, використання критеріїв світових стандартів відповідності завданню аналогових систем було продиктовано подальшою доцільністю у їх вдосконаленні та тотальним переходом в CCTV на нові, у яких «піксель» прийшов на заміну «ТВ лінії». Тут і постало питання: «А чим може бути продиктована гранична доцільність використання критеріїв вирішення оперативних завдань сучасних світових стандартів з CCTV»?

Реалізацію поставлених оперативних завдань перед сучасними інформаційними системи відеоспостереження регламентують відповідні діючі світові стандарти з CCTV: в Англії - BS 7958:2015, СC - EN 50 132, Австралії - AS 4806.2-2015 тощо. Існує також і міжнародний стандарт EN IEC 62676-4:2018.

Одні країни мають розроблені та впроваджені свої стандарти, інші - не розробляють їх, a інтегрують (приймають) стандарти суміжних держав чи регіонів, так як це зробила Україна прийняла міжнародний стандарт EN IEC 62676:2018, який трансформувався у національний стандарт ДСТУ ЕN IEC 62676:2019 під назвою «Системи відеоспостереження охоронного призначення» [8]. В yсіх діючих стандартах CCTV в якості критерія вирішення оперативних задач використовується «щільність пікселів». Але величини цього критерія стосовно різних оперативних задач різняться. У табл. 4 наведено приклад відмінності величин «щільності пікселів», що подано в Європейському, Австралійському і Міжнародному стандартах з CCTV.

Таблиця 4. Критерії вирішення оперативних завдань CCTV світових стандартів

\begin{tabular}{|c|c|c|c|c|}
\hline \multirow{2}{*}{ № } & Вид активності & $\begin{array}{c}\text { Мінімально необхідна } \\
\text { щільність пікселів } \\
\text { (Пікс/м) відповідно } \\
\text { AS 4806 }\end{array}$ & $\begin{array}{c}\text { Мінімально } \\
\text { необхідна щільність } \\
\text { пікселів (Пікс/м) } \\
\text { відповідно } \\
\text { ЕN IEC 62676 }\end{array}$ & $\begin{array}{c}\text { Мінімально } \\
\text { необхідна } \\
\text { щільність } \\
\text { пікселів (Пікс/м) } \\
\text { відповідно } \\
\text { ЕN 50132 }\end{array}$ \\
\hline 1 & Моніторинг & 17 & 15 & 12 \\
\hline 2 & Детектування & 35 & 30 & 25 \\
\hline 3 & Спостереження & 70 & 60 & 62 \\
\hline 4 & Розпізнавання & 175 & 125 & 250 \\
\hline 5 & Ідентифікація & 350 & 250 & 1000 \\
\hline 6 & Інспектування & 1000 & 1000 & \\
\hline
\end{tabular}

Найбільша розбіжність, яка прослідковується в світових стандартах з CCTV, стосується завдань ідентифікації та розпізнавання, а найменша - моніторингу та детектування. Щільність пікселів у відеоспостереженні і щільність пікселів моніторів різні речі. Роздільна здатність моніторів визначається в пікселях на дюйм, а в параметрі «щільність пікселів» камери враховано розмір ії матриці, кількість пікселів матриці, фокусна відстань об'єктива та відстань до об'єкта спостереження.

У відповідності до вимог діючих стандартів, проектувальники разом із замовниками повинні визначитися із задачею, яку має вирішувати кожна камера (моніторинг, детектування, огляд, розпізнання тощо), і при виборі зони ії огляду розрахувати параметри камери і об'єктиву, які в зоні огляду будуть відповідати достатній «щільності пікселів» для обраного завдання. Таким чином, під час проектування таких інформаційних систем потрібно, щоб розрахункове значення «щільності пікселів» відповідало зазначеному стандартному для досягнення визначеного цим стандартом якості зображення. Якщо ж опиратися тільки на фокусну відстань об'єктива - гарантувати виконання вимог стандарту не можливо, якщо не враховувати характеристики матриць.

Вплив параметрів відеокамер на якість зображення об'єкта при вирішенні різних задач розглядали такі практики-дослідники як А.С. Гонта [11], Vlado Damjanovski $[12,13]$, Ю.М. Гедзберг [14], А. Попов [15], John Bigelow [16, 17] та інші.

Вирішення завдання виявлення (детектування) повинно забезпечити можливість оператору поста охорони за зображенням на моніторі виявити об'єкт, який тільки що з'явився серед інших елементів зображення. Виходячи 3 визначення поняття «виявлення», це завдання повинно вирішуватися 3 урахуванням реальної освітленості і оцінюватися ступенем виділення об'єкта контролю із загального фону сцени. 
На рис. 2 наведено зображення групи людей, змодельоване А. Гонтою [11] в програмі «Проектировщик CCTV» під час дослідження оперативної задачі «виявлення», отримане відеокамерами з різною роздільною здатністю.

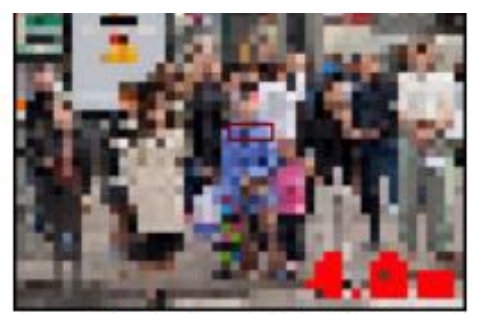

0,4 Мп, 704x576

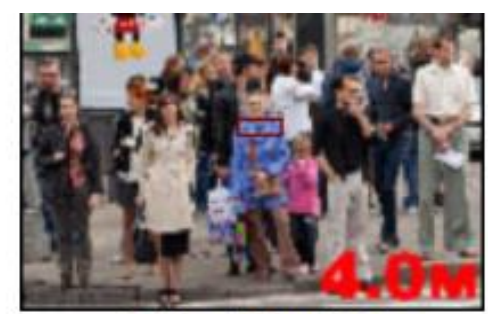

2 Мп, $1920 \times 1080$

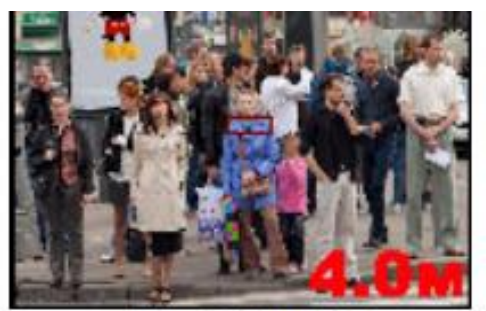

$4 \mathrm{Mn}, 2560 \times 1600$

Рис. 2. Кадри сцени, отримані відеокамерами з однакової відстані з різною роздільною здатністю

Він звернув увагу на те, що для будь-якого розміру об’єктів на екрані монітора існують обмеження щодо вибору роздільної здатності відеокамери. У наведеному прикладі роздільної здатності відеокамери 704×576 недостатньо для вирішення завдання виявлення, оскільки присутня сильна пікселізація зображення. Використання 4 Мп камери з роздільною здатністю $2560 \times 1600$ не дає переваг у «виявленні» в порівнянні з 2 Мп камерою з роздільною здатністю $1920 \times 1080$. Вирішуючи завдання «виявлення», потрібно, щоб роздільна здатність екрана монітора була не гірша за роздільну здатність відеокамери. Протягом значного періоду часу, поки основною роздільною здатністю в системах відеоспостереження був формат 704×576, вважалося, що для «розпізнавання» людини досить, щоб він займав 100 \% висоти екрану монітора. Сучасні аналогові камери (HD відеокамери) мають домінуючу роздільну здатність $1920 \times 1080$ і використовувати критерії у вигляді відсотка від висоти екрана некоректно.

На рис. 3 наведено приклад моделювання впливу роздільної здатності камери на «розпізнавання» об'єкта, отримані А. Гонтою [11] на 20" моніторі.

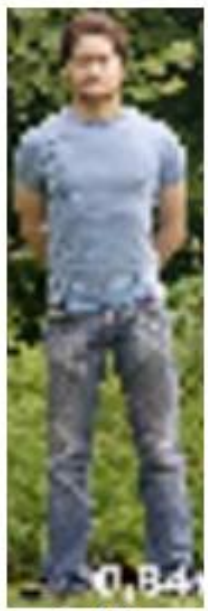

$0,4 \mathrm{Mn}$, $704 \times 576$

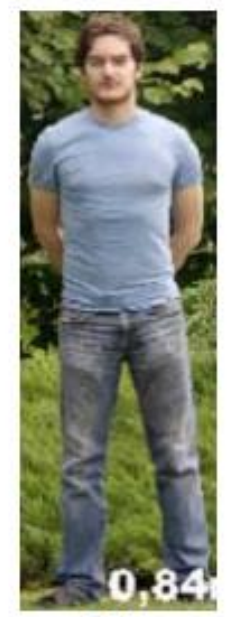

$2 \mathrm{Mn}$, $1920 \times 1080$

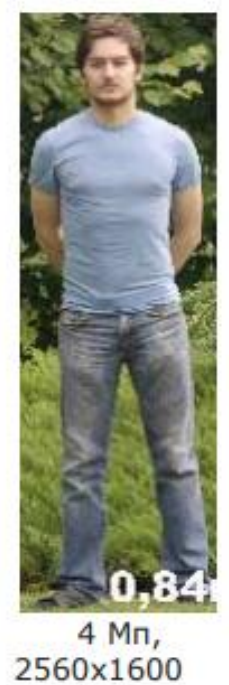

$2560 \times 1600$

Рис. 3. Вплив роздільної здатності камери на розпізнавання об’єкта спостереження

Висота зображення людини щодо вертикального розміру екрана монітора становила $15 \%$.

3 наведених зображень видно, що фокусні відстані у відеокамер були однакові, внаслідок чого розмір людини на екрані сталий, а роздільна здатність зображень відмінна і як наслідок - ступінь «розпізнавання» людини різниться від одного зображення до іншого. У 2 Мп камери якість зображення достатня для детального «розпізнавання», а кадр 34 Мп камери дозволить вирішити завдання «ідентифікації» людини.

При вирішенні завдань «розпізнавання» спочатку потрібно зрозуміти в яких умовах перебувають об'єкти спостереження. Якщо положення об'єктів статичне, вони є нерухомими, це один підхід і для вирішення такого завдання з розпізнавання потрібно визначити фокусну відстань об’єктива і роздільну здатність камери. Якщо ж об’єкти знаходяться в русі, то кількість необхідних 
параметрів збільшується, і для вирішення таких завдань потрібно ще визначити значення витримки електронного затвора. Витримку електронного затвора необхідно встановлювати для того, щоб отримати чітке не змазане зображення об’єкта, що рухається в кожному кадрі.

Питання трансформації ТВЛ в пікселі досліджували А.С. Гонта [11], Vlado Damjanovski [13], John Bigelow $[16,17]$ та інші. Вони також розглядали теорію зміни щільності просторової роздільної здатності, яку тепер застосовують проектувальники CCTV для розрахунку можливості «виявлення» або «ідентифікації» будь-якого об'єкта, до якого у користувача може виникнути інтерес: особа, номерний знак, гральна карта, номінал купюри тощо.

Теорія зміни просторової щільності пікселів передбачає знаходження такої відстані від камери до об'єкта, на якій кількість пікселів на 1 метр ширини сектора спостереження (лінійного поля зору) становить наперед задане значення. Дану теорію пояснює схема (рис. 4) сектора спостереження, на якій продемонстровано чому камери 3 високою роздільною здатністю будуть на екрані монітора створювати зображення об'єкта спостереження набагато менших розмірів ніж камери з низькою роздільною здатністю.

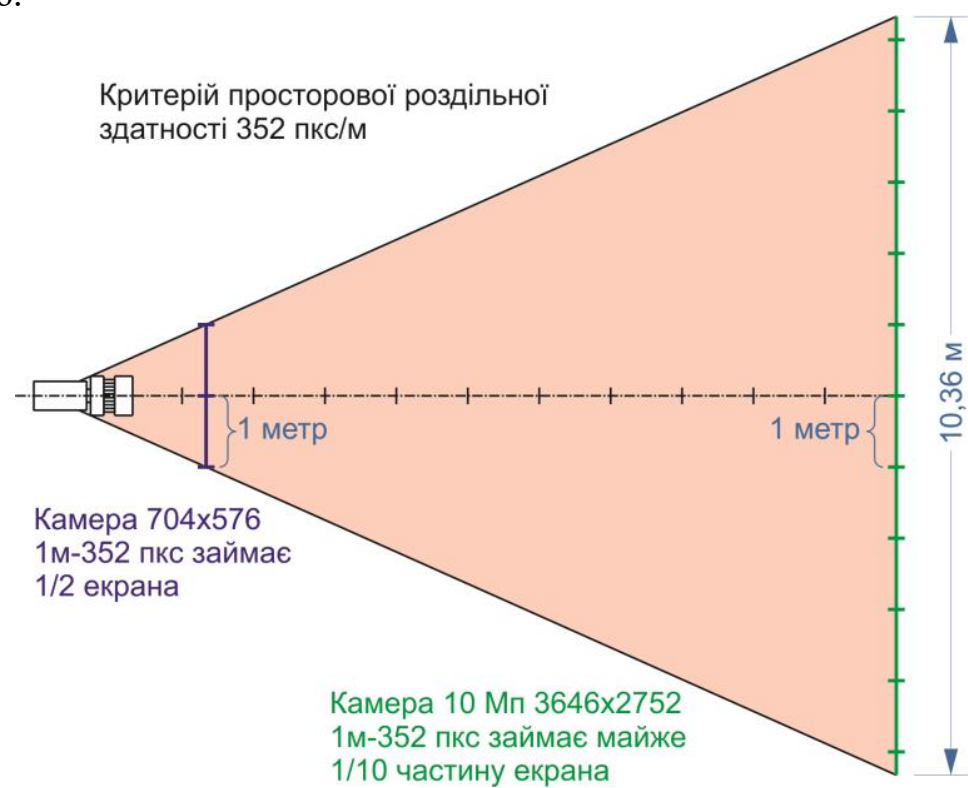

Рис. 4. Зміна просторової щільності камер з різною роздільною здатністю та однаковою фокусною відстанню

Фокусні відстані об’єктивів в даному випадку однакові. Зі схеми видно, що один метр лінійного поля зору для 10 Мп камери займає на екрані в десять разів менше місця ніж зображення, але виведене на екран відеокамерою 3 роздільною здатністю $704 \times 576$ пікселів. Зміна значень просторової роздільної здатності для камер з НD якістю зображення на моніторі проілюстрована на рис. 5.
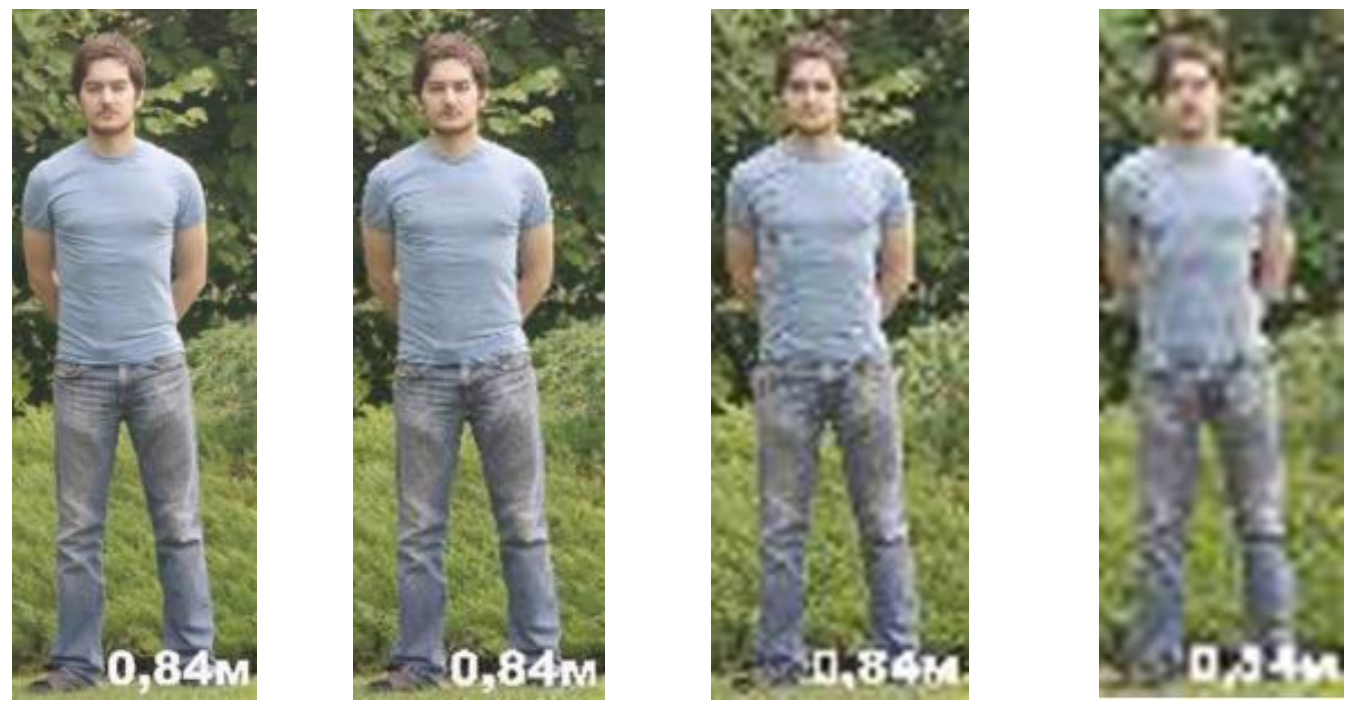

( Терлецький Т.В., Ткачук А.А., Кайдик О.Л., Цебрук В.Р. 


$\begin{array}{cccc}300 \text { пкс/м } & 157 \text { пкс/м } & 80 \text { пкс/м } & 50 \text { пкс/м } \\ \text { Ідентифікація } & \text { Розпізнавання } & \text { Розпізнавання } & \text { Розпізнавання низьке } \\ & \text { високе } & \text { середнє } & \end{array}$

Рис. 5. Зміна просторової роздільної здатності камер

Діапазон відстаней, де необхідно розпізнавати об'єкт досить протяжний, і розташований між зонами «ідентифікації» та «виявлення». У зв'язку з цим А. Гонта запропонував розбити відстані «розпізнавання» на три ділянки:

1. Розпізнавання низьке - об'єкт розташований ближче до межі зони «виявлення». Розмір об’єкта на моніторі невеликий і має погану деталізацію елементів. деталі.

2. Розпізнавання середнє - розмір і якість відображення об'єкта дозволяє описати його основні

3. Розпізнавання високе - об’єкт розташований ближче до області «ідентифікації». Дозволяє чітко описати об'єкт.

Розмір зображень зроблений однаковим для кращого сприйняття спотворень, що проявляються зі зміною просторової роздільної здатності.

В табл. 5 і табл. 6 подано зображення об'єкта, змодельовані А. Гонтою при використанні відеокамер 1/3" з роздільною здатністю 704×576 і 1920×1080 пікселів відповідно. Ці таблиці було створено 3 метою подальшого використання їх під час вибору потрібного параметра камери для вирішення конкретної оперативної задачі.

Таблиця 5. Відображення об’єкта на моніторі при використанні камери 1/3" з роздільною здатністю $704 \times 576$ пкс

\begin{tabular}{|c|c|c|c|c|}
\hline \multirow{2}{*}{$\begin{array}{c}\text { Відстань до } \\
\text { об'єкта, м }\end{array}$} & \multicolumn{4}{|c|}{ Фокусна відстань об’єктива, мм } \\
\hline & 2,8 & 4 & 8 & 16 \\
\hline 4 & & & & \\
\hline 8 & & & & \\
\hline 16 & & & & \\
\hline 32 & & & & \\
\hline 67 & & & & \\
\hline
\end{tabular}

Аналіз інформаційних джерел показав, що в якості сучасного критерія вирішення різних типів оперативних задач CCTV використовується «щільність пікселів», а їх величини в існуючих 
стандартах різняться. Параметр «щільність пікселів» камери враховує розмір їі матриці, кількість пікселів матриці, фокусну відстань об'єктива та відстань до об'єкта спостереження.

Встановлено, що збільшення роздільної здатності відеокамер призводить до збільшення концентрації пікселів на 1 метр лінійного поля зору і покращення якості відображення об'єкта спостереження на більшій відстані від камери. Відповідно до цього зроблено припущення, що 3 появою нових технологій кількість пікселів матриці може досягнути такого значення, яке «розмиє» сучасне розуміння розподілу оперативних задач CCTV і відповідно постане питання про подальшу доцільність використання існуючих критеріїв.

Проведений аналіз наявних робіт практиків-дослідників CCTV з впливу технічних параметрів відеокамер на якість зображення об'єкта при вирішенні різних типів оперативних задач CCTV дозволив встановити, що питання визначення граничної доцільності використання цих критеріїв не розглядалося і $є$ актуальним. 3 огляду на вище сказане і постав інтерес до визначення значення роздільної здатності відеокамери, за досягнення якого, можливо, буде переглянута чи припинена дія критеріїв сучасних стандартів з CCTV. Але потрібно пам'ятати і про можливості людського зору, які $€$ теж обмеженими.

Таблиця 6. Відображення об’єкта на моніторі при використанні камери 1/3" з роздільною здатністю

\begin{tabular}{|c|c|c|c|c|}
\hline \multicolumn{5}{|c|}{$1920 \times 1080$ пкс } \\
\hline \multirow{2}{*}{$\begin{array}{c}\text { Відстань до } \\
\text { об’єкта, м }\end{array}$} & \multicolumn{4}{|c|}{ Фокусна відстань об’єктива, мм } \\
\hline & 2,8 & 4 & 8 & 16 \\
\hline 4 & & & & \\
\hline 8 & & & & \\
\hline 16 & & & & \\
\hline 32 & & & & \\
\hline 67 & & & & \\
\hline
\end{tabular}

Для вирішення цього завдання вирішено взяти за основу теорію зміни просторової роздільної здатності, яку можна реалізувати двома шляхами: аналітичним та комп'ютерним моделюванням 3 використанням прикладних програм, які призначені для проектування CCTV. Використання аналітичного методу з класичною його реалізацією, яка передбачає величезну кількість розрахунків, потребує багато часу. Якщо ж автоматизувати цей процес і використати, наприклад, Excel aбо Matlab - розрахунки прискоряться, та буде отримано необхідні графічні залежності для подальшого їх аналізу. Також можна використати і вже існуючі спеціалізовані онлайн-калькулятори, в яких задаючи 
прогнозовані параметри відеокамери буде встановлено мінімальний розмір об'єкта виявлення, що віддалений від неї на певну відстань, з урахуванням можливостей людського ока.

Застосування комп'ютерного моделювання CCTV, з використанням таких спеціалізованих програм як IP Video System Design Tool, VideoCAD чи інших, в основу роботи яких покладена теорія зміни «просторової щільності», дозволить отримати 3D модель сектору спостереження і аналізувати його. На перший погляд цей варіант $є$ найкращим. Але реалізація цього шляху обмежується, наявною технічною базою (можливостями відеокарти ПК, роздільною здатністю монітора) та наявних бібліотек (баз) існуючих відеокамер і потребує використання методу підбору, який передбачає почергову зміну параметрів камери. Так, наприклад, в IP Video System Design Tool станом на жовтень 2020 року максимальна роздільна здатність відеокамери, що присутня в базі даних, становить 6576x4384 пікселя, що відповідає 29 Мріх. А що, якщо цього значення не буде достатньо для вирішення поставленого завдання?

Попередній аналіз можливих шляхів встановлення граничної доцільності використання згаданих критеріїв дозволив встановити обов'язковість застосування аналітичного методу 3 подальшим, за можливістю, моделюванням сцени відеоспостереження.

У відповідності до сказаного постало завдання у вирішенні наступних питань:

1. Проаналізувати можливості людського ока з точки зору розпізнавання об'єктів та встановити мінімальне значення розміру елемента об’єкта, яке може розрізнити людське око;

3. Описати аналітично взаємозв'язок основних технічних параметрів відеокамер із зміною «просторової щільності» та мінімальним допустимим значенням розміру елемента об'єкта спостереження;

4. Отримати графічні залежності зміни просторової щільності від основних технічних параметрів відеокамер.

Реалізація цих завдань дозволить у подальшому встановити значення роздільної здатності матриці, за якої подальше використання існуючих критеріїв вирішення оперативних задач буде не доцільне.

Список бібліографічного опису

1. BS EN 62676-4:2015 Video surveillance systems for use in security applications. Application guidelines. [Електронний ресурс]. URL: https://www.thenbs.com/PublicationIndex/documents/details?Pub=BSI\&DocID=311425.

2. BS 7958:2009 CCTV management and operation code of practice. [Електронний ресурс].

URL: https://infostore.saiglobal.com/en-us/Standards/BS-7958-2009-2009-263522_SAIG_BSI_BSI_609599/.

3. BS 7958:2015 Closed circuit television (CCTV) - management and operation - code of practice. [Електронний ресурс].

URL: https://www.thenbs.com/PublicationIndex/documents/details?Pub=BSI\&DocID=312704.

4. $\begin{array}{lllllll}\text { BS } & \text { 8418:2015 CCTV Systems for Installers. [Електронний pecypc]. }\end{array}$ https://www.riscauthority.co.uk//index.cfm?originalUrl=free-document-library/RISCAuthority-Library_detail.bs-8418-2015-

installation-and-remote-monitoring-of-detector-activated-cctv-systems-code-of-

practice.html\& tkn=FD45BCF0\%2D18D2\%2D4EC8\%2DB8DDA7701FEA1C54.

5. NTCIP 1205. Object Definitions for Closed Circuit Television (CCTV) Camera Control. [Електронний pecypc]. URL: https://www.standards.its.dot.gov/Factsheets/Factsheet/83.

6. I.S. 199:1987, Alarm systems - CCTV surveillance for use in security applications. [Електронний pecypc]. URL: https://www.nsai.ie/certification/product-certification/security-systems/.

7. AS 4806.2 - 2006 Closed Circuit Television (CCTV): Application Guidelines. [Електронний pecypc]. URL: https://www.techstreet.com/standards/as-4806-2-2006?product_id=2068183.

8. EN 50132-7:2012. Alarm systems - CCTV surveillance systems for use in security applications - Part 7: Application guidelines. [Електронний ресурc]. URL: https://www.slideshare.net/malvvv/en-501327.

9. ДСТУ EN IEC 62676-5:2019 Системи відеоспостереження охоронного призначення. [Електронний pecypc]. URL: http://online.budstandart.com/ua/catalog/doc-page.html?id_doc=83148.

10. Идентификация, распознавание и детектирование людей по европейскому стандарту EN 50 132-7. / М. Шумейко // Системы безопасности" №3, 2015. [Електронний ресурс].

URL: http://library.tsu.tula.ru/files/elect_periodical/system_securiti3.pdf.

11. Гонта А.С. Практическое пособие по видеонаблюдению - Москва: 2017 г. - 188 с.

12. Владо Дамьяновски CCTV. Библия видеонаблюдения. Цифровые и сетевые технологии / Пер, с англ. - М.: ООО «Ай-ЭсЭс Пресс», 2006, - 480 c.

13. Vlado Damjanovski. Case study: Evaluating Face Identification of an IP cameras with the ViDi Labs test chart v.5.2. [Електронний ресурc]. URL: https://vidilabs.com/download/vidilabs-test-chart-case-study.pdf.

14. Гедзберг Ю.М. «Охранное телевидение». - Москва: Горячая линия-Телеком, 2005. - 312 с.

15. А. Попов. Моя азбука видеонаблюдения. - Санкт-Петербург: ООО «Издательство «Карелико», 2013, - 248 с.

16. About Pixel Densities And What They Mean / John Bigelow // Security solutions, 2017. [Електронний pecypc]. URL: https://www.securitysolutionsmedia.com/2017/08/01/about-pixel-densities-and-what-they-mean/

17. The ViDiLabs Calc application. Security solutions / John Bigelow // Security solutions, 2016. [Електронний ресурс]. URL: https://www.securitysolutionsmedia.com/2016/10/28/the-vidilabs-calc-application/.

() Терлецький Т.В., Ткачук А.А., Кайдик О.Л., Цебрук В.Р. 


\section{References}

1. BS EN 62676-4:2015 Video surveillance systems for use in security applications. Application guidelines. [Electronic resource]. URL: https://www.thenbs.com/PublicationIndex/documents/details?Pub=BSI\&DocID=311425.

2. BS 7958:2009 CCTV management and operation code of practice. [Electronic resource].

URL: https://infostore.saiglobal.com/en-us/Standards/BS-7958-2009-2009-263522_SAIG_BSI_BSI_609599/.

3. BS 7958:2015 Closed circuit television (CCTV) - management and operation - code of practice. [Electronic resource]. URL: https://www.thenbs.com/PublicationIndex/documents/details?Pub=BSI\&DocID=312704.

4. $\mathrm{BS} \quad 8418: 2015$ CCTV Systems for Installers. [Electronic resource]. URL: https://www.riscauthority.co.uk//index.cfm?originalUrl=free-document-library/RISCAuthority-Library_detail.bs-8418-2015-

installation-and-remote-monitoring-of-detector-activated-cctv-systems-code-ofpractice.html\& tkn=FD45BCF0\%2D18D2\%2D4EC8\%2DB8DDA7701FEA1C54.

5. NTCIP 1205. Object Definitions for Closed Circuit Television (CCTV) Camera Control. [Electronic resource]. URL: https://www.standards.its.dot.gov/Factsheets/Factsheet/83.

6. I.S. 199:1987, Alarm systems - CCTV surveillance for use in security applications. [Electronic resource]. URL: https://www.nsai.ie/certification/product-certification/security-systems/.

7. AS 4806.2 - 2006 Closed Circuit Television (CCTV): Application Guidelines. [Electronic resource]. URL: https://www.techstreet.com/standards/as-4806-2-2006?product_id=2068183.

8. EN 50132-7:2012. Alarm systems - CCTV surveillance systems for use in security applications - Part 7: Application guidelines. [Електронний ресурc]. URL: https://www.slideshare.net/malvvv/en-501327.

9. ДСТУ EN IEC 62676-5:2019 Системи відеоспостереження охоронного призначення. [Electronic resource]. URL: http://online.budstandart.com/ua/catalog/doc-page.html?id_doc=83148.

10. Identification, recognition and detection of people according to the European standard EN 50 132-7. / M. Shumeiko // Security Systems "No. 3, 2015. [Electronic resource]. URL: http://library.tsu.tula.ru/files/elect_periodical/system_securiti3.pdf.

11. Gonta A.S. A practical guide to video surveillance - Moscow: 2017 - 188 p.

12. Vlado Damjanovski. CCTV. The CCTV Bible. Digital and network technologies / Per, from English. - Moscow: OOO "A-Es-EsPress", 2006, - 480 p.

13. Vlado Damjanovski. Case study: Evaluating Face Identification of an IP cameras with the ViDi Labs test chart v.5.2. [Electronic resource]. URL: https://vidilabs.com/download/vidilabs-test-chart-case-study.pdf

14. Gedzberg Y.M. Security television. - Moscow: Hotline-Telecom, 2005. - 312 p.

15. A. Popov. My ABC of video surveillance. - St. Petersburg: "Publishing house" Kareliko ", 2013, - 248 p.

16. About Pixel Densities And What They Mean / John Bigelow // Security solutions, 2017. [Electronic resource]. URL: https://www.securitysolutionsmedia.com/2017/08/01/about-pixel-densities-and-what-they-mean/

17. The ViDiLabs Calc application. Security solutions / John Bigelow // Security solutions, 2016. [Electronic resource]. URL: https://www.securitysolutionsmedia.com/2016/10/28/the-vidilabs-calc-application/ 